\title{
Annual Equivalent Value, Benefit Cost Ratio, and Composite Performance Index as Valuation Appraisal Support of Teakwood Plantation
}

\author{
Sugiharto Soeleman ${ }^{1 *}$, Endang Gumbira-Sa'id ${ }^{2}$, Heny Kuswanti Suwarsinah Daryanto ${ }^{3}$, Arif Imam Suroso ${ }^{4}$ \\ ${ }^{1}$ Graduate Study Program of Business and Management, Graduate School, Bogor Agricultural University, \\ Jl. Raya Pajajaran Bogor, Indonesia 16151 \\ ${ }^{2}$ Department of Agroindustrial Technology, Faculty of Agricultural Technology, Bogor Agricultural University, \\ Academic Ring Road, Bogor, Indonesia 16680 \\ ${ }^{3}$ Department of Resources and Environmental Economics, Faculty of Economics and Management, Bogor Agricultural \\ University, Academic Ring Road, Bogor, Indonesia 16680 \\ ${ }^{4}$ Department of Management, Faculty of Economics and Management, Bogor Agricultural University, Academic Ring Road, \\ Bogor, Indonesia 16680
}

\section{Received Februari 17, 2014/Accepted April 16, 2014}

\begin{abstract}
Teak (Tectona grandis L.f) is a premium high-value hardwood species being viewed as the most preferred species for investment opportunity. Recently, there has been a gradual move away from state control of teakwood plantation toward the participation of private enterprises. Several enterprises offer investment opportunity of teakwood plantation in which one of the main selling points being offered is a quick harvesting schedule. A quick harvesting time, however, might not provide the best outcome to the investors. This research exercise and compare the valuation appraisal of different harvesting schedules. The research focused on project planning, enterprise budget, financial projection, and valuation measurements to arrive at overall appraisal. To avoid any possible bias of individual investor's preference on common valuation criteria such as total investment, net cash flow (NCF), net present value $(N P V)$, internal rate of return (IRR), profit on investment (P/I), and payback period (PBP), 3 others criteria namely benefit cost ratio (BCR), annual equivalent value ( $A E V)$, and composite performance index (CPI) have been applied to arrive at a more fair valuation. It is concluded that the longer the harvesting schedule, the better valuation outcome could be achieved, and therefore, investors should critically review any investment proposal in accordance to their preference on valuation criteria.
\end{abstract}

Keywords : annual equivalent value, benefit costratio, composite performance index, valuation appraisal

*Correspondenceauthor,email:ss_aei@yahoo.co.id,telp:+62-811844767,fax:+62-21-30014994

\section{Introduction}

Several authors suggested agricultural expansion to meet additional food due to population growth led to deforestation and environmental degradation (Amacher et al. 2008; Fuglie 2010; Kangalawe \& Lymo 2010; Quaye et al. 2010). Benhin (2006) stated that deforestation in developing countries was the cheapest way to increase agricultural production. Despite the need for productive agricultural lands there are unproductive marginal drylands scaterred all over the world that have not been developed mainly for economic reasons. The drylands that cover about $41 \%$ of the Earth's land surface support approximately $36 \%$ of the human population (Washington-Allen et al. 2010). Despite extensive research on dryland agriculture such as in Morroco, Israel, Iraq, Chile, USA, Iran, and Australia (Ryan et al. 2007; Rabia et al. 2008; Abi-Ghanem et al. 2009; Young et al. 2010; Acosta-Martinez et al. 2011; Carberry et al. 2011; Kademani 2011), none of them were dealing with teak plantation in marginal dryland as it was studied by Sugiharto (2013).

Sugiharto (2013) studied the communities' preference and financial benefits between standalone teak plantation and intercropping other commodities in between teak plantation. Similar intercrops farming in between teakwood plantation were carried out in India in which teak plantation were successfully intercroped with Oryza sativa (Lalramnghinglova \& Jha 1996). In Ghana, teak trees were inter-planted with a mixture of food crops such as maize, yam, tomatoes, cassava, and groundnuts (Djagbletey \& AduBredu 2007).

Teak (Tectona grandis L.f) is a premium high-value hardwood species with unique characteristics for its attractive appearance, durability, decay resistance, and easy workability (Hallet et al. 2011). With its high wood quality and excellent growth performance, teak wood plantation had been one of the most preferred species for investment opportunity (Pérez 2008). Initially, teakwood plantation in Indonesia was managed by the government's enterprise, Perum Perhutani; however, in recent years there has been a gradual move away from state control of such plantation toward the participation of local people wich improves local livelihoods and reduces poverty (RECOFTC 2010). 
Recent campaign by several private enterprises in Indonesia to invest in teakwood plantation have been focused on quick harvesting schedule as the main selling point. This might give a misleading information to the investors since the opportunity to earn higher yield is prevented due to limited knowledge of getting optimum outcome from a better harvesting strategy. This research exercises the investment appraisal of different harvesting strategies of standalone teak plantation proposed by earlier brochures and publications (Soeroso \& Poedjowadi 2009; Hallet et al. 2011; JAR 2012; Soeleman et al. 2012; Soeleman et al. 2013; Sugiharto 2013). It is expected that by comparing different harvesting strategies, investors are able to critically review any investment proposal that yield the best outcome which fit their valuation criteria preference.

The investment appraisal process was carried out by using the method of enterprise budget as being suggested by previous authors (Gittinger 1982; Godsey 2008; Kay et al. 2012). In addition to common valuation criteria of total investment, net cash flow (NCF), net present value (NPV), internal rate of return (IRR), profit on investment (P/I), and payback period (PBP); other criteria of annual equivalent value (AEV), benefit cost ratio (BCR) and composite performance index (CPI) had been applied.

\section{Methods}

The framework of this research was mainly focused on project planning, enterprise budget, financial projection, and valuation measurements to arrive at overall appraisal. Figure 1 shows the investment appraisal framework being adapted from Gittinger (1982) and Sugiharto (2013).
Gittinger (1982) did not include AEV, BCR, nor CPI which were incorporated in Sugiharto (2013). While Sugiharto (2013) compared AEV and BCR only, this article incorporates CPI to be compared with AEV and BCR. Further, each field data being used in this article was measured with additional 4 measurements compare to the data being used in Sugiharto (2013), so that the quality of data are expected to be more reliable. The financing plan that was discussed in Sugiharto (2013) is not elaborated in this article. However, the financing strategy being proposed by Sugiharto (2013) is quoted in this article.

The technical aspect, institutional aspect, and social aspect were not the focus of this research. The project planning involved the determination of location, scale of the program, timing of the activities, and manpower being employed. The enterprise budget consists of the allocation of capital investment and operating expenses as well as the calculation of revenue and its tax consequences. Price trend and inflation trend were incorporated into the valuation. Sugiharto (2013) detailed the projected enterprise budget consisting of projected income statement, projected balance sheet, and projected cash flow statement; however, for the purpose of valuation measurement, only projected cash flow statement was used.

The common valuation criteria being calculated were total investment, NCF, NPV, IRR, P/I, and PBP (Godsey 2008). To overcome any possible bias in the decision making process based on the above common valuation criteria, additional tools of AEV (Godsey 2008), BCR (Gittinger 1982), and CPI (Marimin \& Maghfiroh 2010) had been employed.

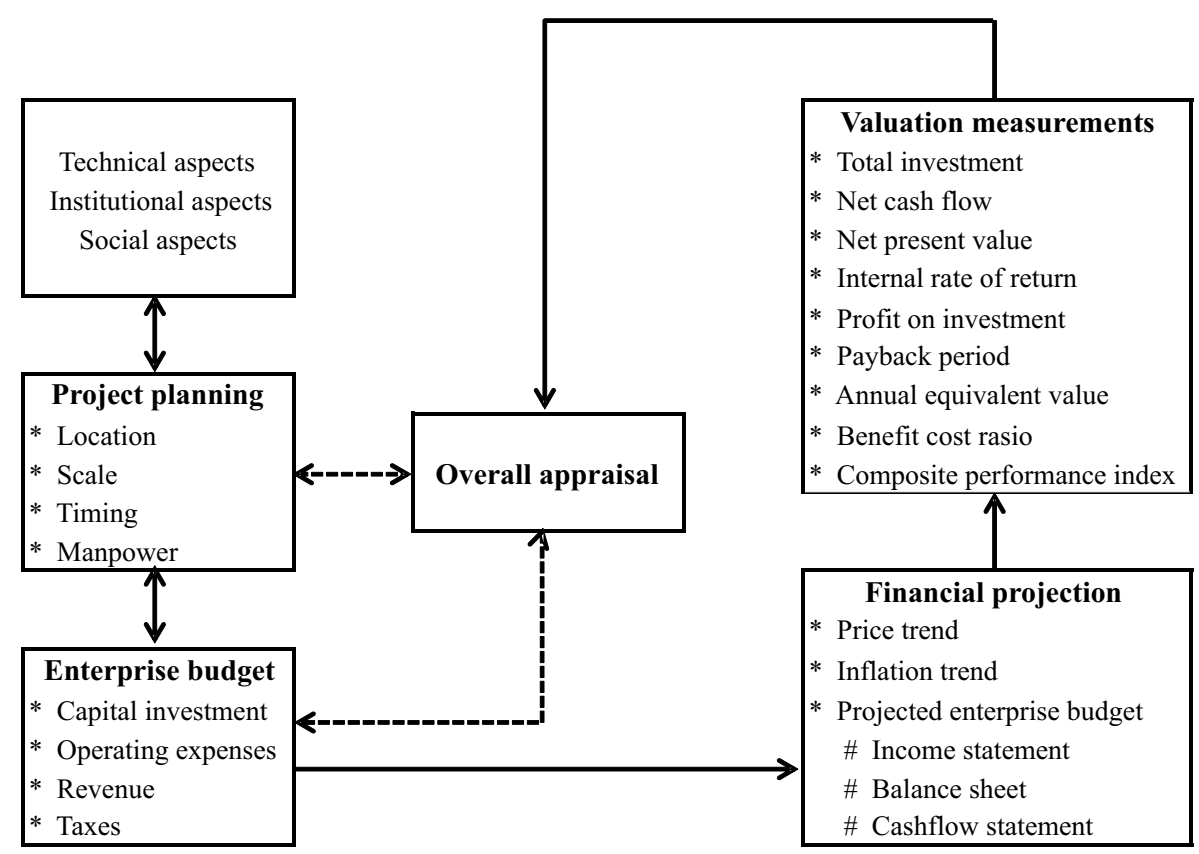

Figure 1 Research framework of investment appraisal. 
Location, scale, time frame, and manpower For the purpose of the model, a field experimental research has been carried out in Gunung Kidul Regency, Yogyakarta Province, Indonesia (Figure 2). Yogyakarta Province covers an area of $3,186 \mathrm{~km}^{2}$ in the mid-southern part of Java Island situated betweens $S 7^{\circ} 3^{\prime}-8^{\circ} 12^{\prime}$ and $\mathrm{E} 11^{\circ} 00^{\prime}-11^{\circ} 50^{\prime}$ with the population of nearly 3.5 million. The province is devided into 5 regencies namely Kulon Progo, Bantul, Gunung Kidul, Sleman, and Kodya Yogyakarta. Gunung Kidul Regency is located between $\mathrm{S} 7^{\circ} 46^{\prime}-\mathrm{S}^{\circ} 09^{\prime}$ and E110 $21^{\prime}-\mathrm{E} 110^{\circ} 50^{\prime}$ covering approximately $46 \%$ of Yogyakarta Province.

An area of 5 ha was selected to the south-eastern part of Gunung Kidul Regency, located approximately $80 \mathrm{~km}$ to the south-east of the city of Yogyakarta. The activities were started in June 2008 and evaluated in December 2013. To carry out the activities on a 5 ha of land, 1 agricultural graduate, and 3 local farmers were employed.

Research design This research was considered as field exploratory study in which limited information on similar issues was available in the past. A noncontrived research was conducted in natural environment where the researcher's interference was minimal to moderate. Such interference included the selection of clones of teak trees, treatment, and the strategy for the start of the activities as well as the timing of harvesting. The time horizon of the study covered both cross-sectional and longitudinal studies. Face-to-face interviews carried out to gain experts' preference on valuation criteria are considered as cross-sectional study. The observation for the growth of teak's diameter and height are consired as longitudinal study in which more than one points in time being carried out in longitudinally across a period of time. The scaling mechanism being used was ordinal in which the data were rank-ordered according to some preferences.
Valuation measurement comparison In recent years, several private enterprises offering investment in teak plantation with different scenarios in term of investment value, schedule of harvesting and profit sharing. This research was focused on the valuation comparation of the following harvesting strategies:

1 Model 1: Company " $X$ " offering an early harvesting of all teak plantation at the age of 5 years (Soeroso \& Poedjowadi 2009).

2 Model 2: Company "Y" offering harvesting schedule at the age of 7 years $(50 \%), 10$ years $(25 \%)$, and 13 years (25\%) (JAR 2012).

3 Model 3: harvesting schedule at the age of 3 years ( $36 \%)$, 6 years $(14 \%), 10$ years $(14 \%), 15$ years $(9 \%)$ and 23 years $(27 \%)$ (Hallet et al. 2011).

4 Model 4: harvesting schedule after the teak trees reach an age of 14 years old to the amount of $10 \%$ each year and continues the harvesting of $10 \%$ each year until the last $10 \%$ of planted trees (Sugiharto 2013).

Except Model 1, the trees being harvested were started with the smallest diameter as part of the thinning activities to allow good quality trees grow better.

Sample design and data collection The time schedule of plantation were from June 2008 to February 2011 at a total of 4,650 trees and at the date of measurement (December 2013) there were 4,068 trees survived representing $87.5 \%$ of the planted trees. The soils range from the sandy to shally soils as well as in the karst dominated rocks. Four different clones of teak trees were planted in the middle of dry season, at the beginning of rainy season, and at the end of rainy season. The teak density were range $1,100-2,500$ trees $^{-1}$ with grid spacings of $3 \times 3 \mathrm{~m}$ and $2 \times 2 \mathrm{~m}$ respectively. The sampling methods employed were systematic random sampling (measured in every 5 trees) and cluster sampling (based on

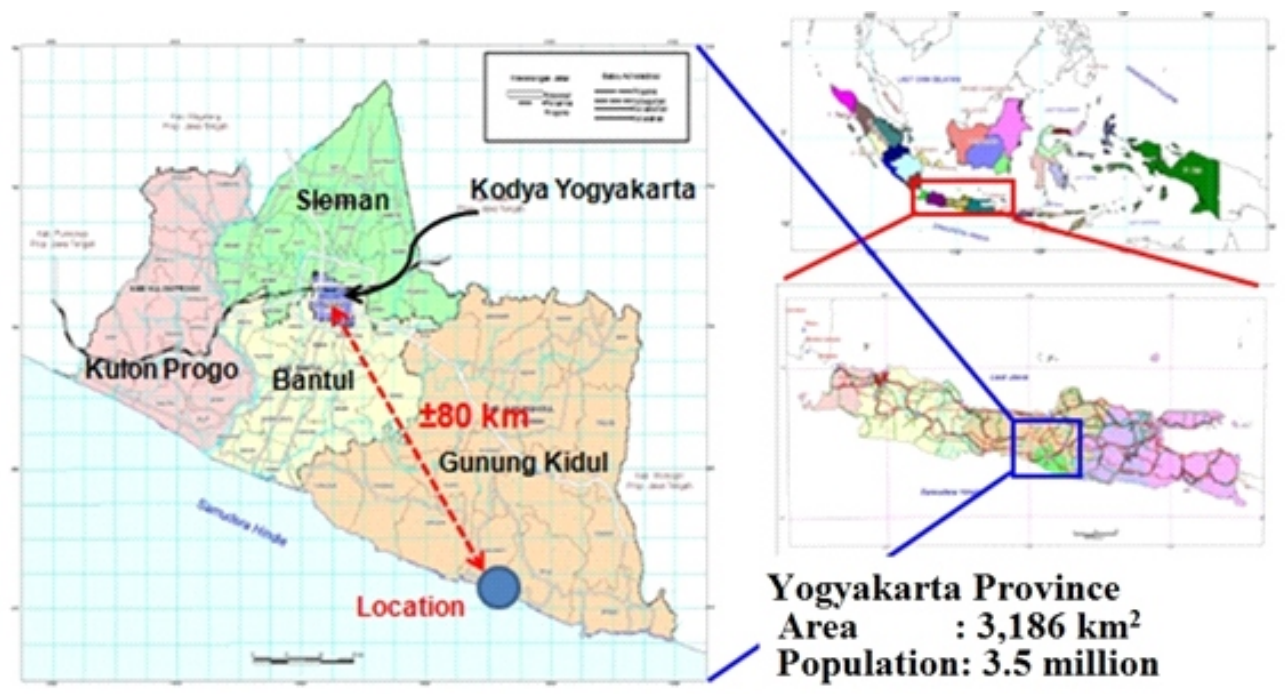

Figure 2 Research location in Gunung Kidul Regency, Yogyakarta Province, Indonesia. 
the plant locations, time of plantations, and teak's clones). The data used were both primary data and secondary data. The primary data was obtained specifically designed for the purpose of the study such as direct measurement of the diameters and heights of teak trees and data were obtained through face-to-face interviews for the purpose of getting experts' preference on valuation criteria. The secondary data was obtained from the existing information such as research publications (Pérez 2008; Pramono et al. 2010; Hallet et al. 2011; Sugiharto 2013), government publications and decrees (Perhutani 2011), and brochures (Soeroso \& Poedjowadi 2009; JAR 2012). From July 2011 to December 2013, 648 trees were observed at every 5 trees interval in term of their diameters ( $d b h$, diameter at breast height) and heights (from the surface to free from branches). Each sample had been measured between 6-10 times at an interval of 3 months period. Before being analized, the samples were screened to exclude any outliers and irregulatities. The first step was forecasting the trend projection of the diameter's growth of the individual sampled trees by using time series method. Further, the errors of forecasted diameters were calculated by using mean absolute deviation, mean square of error, and mean absolute error. After being screened, there were 546 reliable samples for further analysis.

Analytical tools For the purpose of investment decisionmaking process it is important to estimate the capital costs, operating expenses, and revenues; and to evaluate quantitatively for accepting or rejecting any proposed activity. Common quantitative methods were applied such as total investment, NCF, NPV, IRR, P/I, and PBP. Other than these commonly used evaluation techniques, 3 other techniques were applied namely AEV, BCR, and CPI.

The AEV is to estimate a level of income stream that would have the same net present value as the actual cash flows (Godsey 2008) and being defined as shown in Equation [1]:

$$
\mathrm{AEV}=\frac{\mathrm{NVP}}{\sum_{t=1}^{n} \frac{1}{\left(1+k^{*}\right)^{t}}}
$$

note: $\mathrm{NPV}=$ net present value

$$
k^{*}=\text { internal rate of return }
$$

The BCR is another type of discounted measure of project in which the present worth of the benefits stream is divided by the present worth of the cost stream with the following mathematical definition (Gittinger 1982) as shown in Equation [2]:

$$
\mathrm{BCR}=\frac{\sum_{t=1}^{t=n} \frac{\mathrm{B} t}{(1+i)^{t}}}{\sum_{t=1}^{t=n} \frac{\mathrm{C}_{t}}{(1+i)^{t}}}
$$

note: $\mathrm{B}_{t}=$ benefit in each year

$\mathrm{C}_{t}=$ cost in each year

$t=1,2,3, \ldots, \mathrm{n}$

$n=$ number of years

$i=$ discount rate
The CPI is one of the tools being utilized to make a decision based on performance valuation of several alternatives and several criteria (Marimin \& Maghfiroh 2010). This technique was choosen to solve unequal valuation criteria and a mixture of valuation scale. There are 4 steps namely initial valuation matrix, transformed matrix, alternative values and priority ranking. After the models being valued as initial valuation matrix, the transformed matrix is defined by identifying the positive and negative trends of the criteria. For positive trend criteria, the higher the value-the better the output; whereas for negative trend criteria, the lower the value-the better the output. Further, for positive trend criteria, the minimum value is transformed to "100" and other values are transformed proportionally higher whereas for negative trend criteria, the minimum value is transformed to " 100 " and other values are transformed proportionally lower. After a transformed matrix is defined, a summation of all criterias multiplied by their weight factors of each model will define alternative values of the model and being rank in accordance to their preferences.

\section{Results and Discussion}

In December 2013, the age of the trees were 35-66 months which imply more data measurements compare to data being used in Sugiharto (2013). The measured diameters of the trees were $3.36-21.72 \mathrm{~cm}$, and the heights were $2.0-$ $14.00 \mathrm{~m}$, respectively. The average diameters growth were $1.56-2.65 \mathrm{~cm}$ year $^{-1}$ and the average height growth were 1.15-2.34 $\mathrm{m}$ year $^{-1}$. Since the age of the teak trees were less than 6 years old, future diameters and heights of the teak were forecasted using the pattern of similar tree growth being published from the data from Costa Rica (Pérez 2008) and Indonesia (Pramono et al. 2010) (Figure 3).

The growth performance in diameters and heights in the first 66 months in Gunung Kidul plantation was less than that of the growth performance in Costa Rica and other part of Indonesia. Therefore, the forecasted growth of diameters and heights in Gunung Kidul was proportionally adjusted to the growth of diameters of teakwood trees in Costa Rica and other part of Indonesia.

Enterprise budget An enterprise budget provides an estimation of the potential revenue, expenses, and profit for a single enterprise. There are 3 main component of enterprise budget namely capital investment or fixed costs, operating expenses or variable costs, and revenue (Godsey 2008). Fixed costs are costs attributed to resource ownership that occur regardless of any productive activities (Godsey 2008). The capital investment for 5 ha of teakwood plantation consists of water well (IDR12,500,000 with useful life of 25 years), field camp (IDR10,000,000 with useful life of 15 years), chainshaws (IDR5,000,000 with useful life of 10 years), and other items (IDR2,500,000 with useful life of 10 years).

Operating costs are costs attributed to the productive use of resources including payments for establishment, maintenance, harvesting, and marketing (Godsey 2008). The operating costs in this research involved establishment (field 

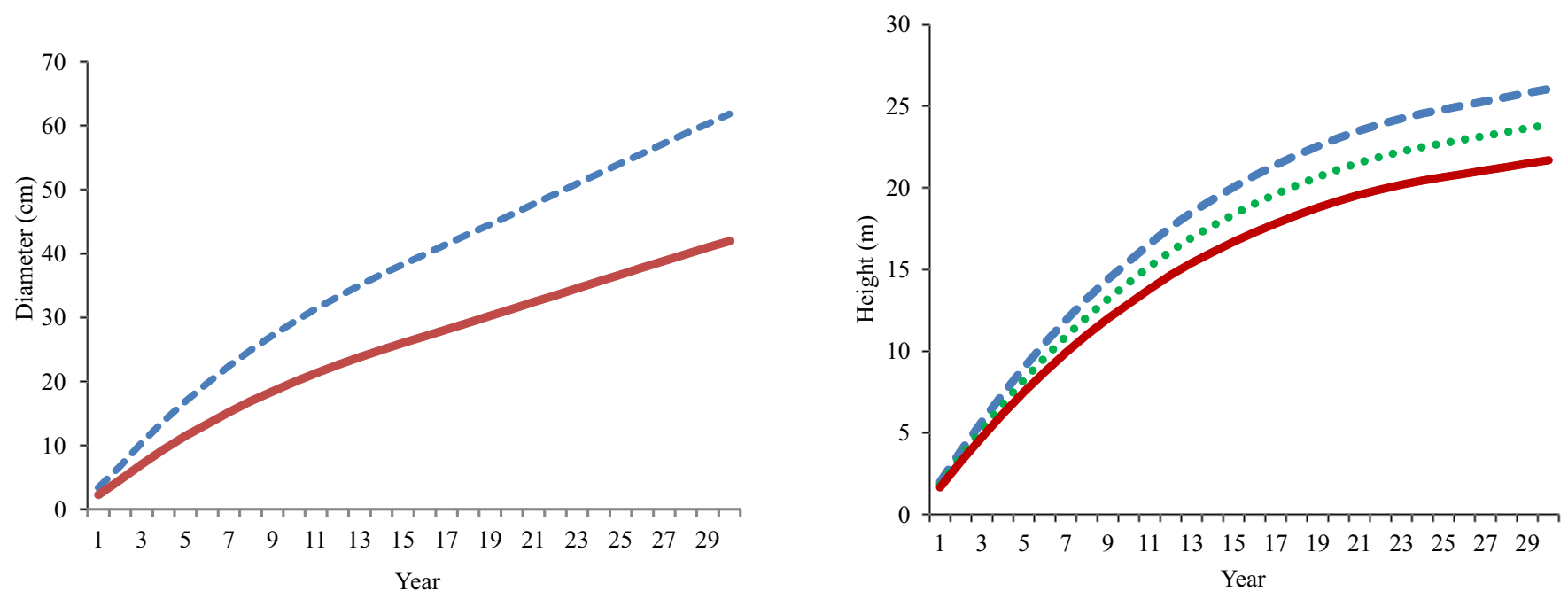

Figure 3 Forecasted diameter and height of teak wood reported by Pérez (2008) and Pramono et al. (2010). Perez (2008) (---), Pramono et al. (2010) (…), Own Model $(\longrightarrow)$.

survey and socialization at IDR500,000 $\mathrm{ha}^{-1}$, land clearing at IDR1,000,000 ha ${ }^{-1}$, planting expenses at IDR1,000,000 $\mathrm{ha}^{-1}$, planlet price at IDR13,500 tree $\left.{ }^{-1}\right)$, maintenance (1 graduate professional at IDR1,750,000 person ${ }^{-1}$ month $^{-1}, 3$ farmers at IDR850,000 person ${ }^{-1}$ month $^{-1}$, land rental at IDR3,500,000 hectare $^{-1}$ year ${ }^{-1}$, fertilizer at IDR750 $\mathrm{kg}^{-1}$ tree $^{-1}$ month $^{-1}$, harvesting costs at IDR200,000 $\mathrm{m}^{-3}$, and overhead of $10 \%$ of total operating costs).

The forecasted revenue streams were calculated based on forecasted production volume and forecasted price of harvested teak wood whereas the production volume was defined from the forecasted diameter and forecasted height of teak wood plantation. The price of teak wood for the year 2012 published by Perhutani (2011) is being averaged in Table 1.

The corporate taxable income in Indonesia was calculated based on the gross income after being deducted from, among others, the costs and expenditures, depreciation and amortisation, pension fund, operating loss, unrecoverable receivable, social charity expenditures, natural disaster, education, sport, etc. For the purpose of this research, a fixed tax rate of $25 \%$ was applied to profit being generated from the harvested teak wood.

Financial projection From the statistic data in the last 25 years, the price of teak wood doubles every 5 years (JAR 2012). This is equivalent to approximately $15 \%$ increases year $^{-1}$ which was used to evaluate the models. For the purpose of the research, an inflation of $6 \%$ were used. Sugiharto (2013) elaborated the projected income statement, projected balance sheet, and projected cash flow statement; however, for the purpose of this paper only projected cash flow statement was used.

Valuation measurement An in-depth interviews with experts representing the board of a public company, individual investor, and an executive of a private company were carried out. Experts' preferences were valued between 1 (the lowest) and 5 (the most preferred). Sugiharto (2013) indicated that from the interviews, the IRR criteria was the highest criteria considered by all respondents with an average weight factor of 0.25 . This criterium was followed by NCF and P/I criteria with an average weight factor of 0.20 . The NPV and PBP share the same weight factor of 0.15 whereas the weight factor of total investment is 0.05 .

One of the critical issue to be used for valuation measument is the determination of required rate of return. The required rate of return or discount rate being used for financial valuation was calculated using the formula $E\left(R_{i}\right)=$

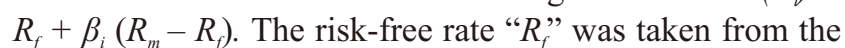
government's long term loan being issued by the Government of Indonesia (Minister of Finance 2012) whereas the " $\beta$ " (being defined as the ratio of the variability on the common stocks of the firm to the variability in the average return on the common stocks of all firms; Salvatore 2008) was taken by averaging all available " $\beta$ " data of public companies in agriculture being listed in Indonesia (Reuters 2013). $\left(R_{m}-R_{f}\right)$ is market risk premium in Indonesia (Fernández et al. 2011). The calculated required rate of return was 11.71 and, therefore, for the purpose of this research, the required rate of return of $12 \%$ was used (Sugiharto 2013).

Valuation results The valuation of Model 1, Model 2, Model 3 , and Model 4 were compared in term of total investment, NCF, NPV at a discount rate of $12 \%$, IRR, P/I, and PBP. The valuation output of the above models is demonstrated in Table 2.

From the valuation, Model 1 is superior in terms of lowest total investment (i.e. IDR610.91 million) and the fastest payback period (i.e. 5.92 years) whereas Model 3 superior in terms of highest profit on investment (i.e. 335.29). In terms of NCF, NPV, and IRR, Model 4 is the best yielding an NCF of 
Table 1 Average teak price per $\mathrm{m}^{3}$ for the year 2012

\begin{tabular}{cc}
\hline $\begin{array}{c}\text { Diameter } \\
(\mathrm{cm})\end{array}$ & $\begin{array}{c}\text { Price per } \mathrm{m}^{3} \\
(\mathrm{IDR})\end{array}$ \\
\hline $4-7$ & 767,500 \\
$10-13$ & $1,509,500$ \\
$16-19$ & $2,366,500$ \\
$21-23$ & $2,937,200$ \\
$24-26$ & $3,534,600$ \\
$27-29$ & $4,032,200$ \\
$30-34$ & $5,541,167$ \\
$35-39$ & $6,234,000$ \\
$40-44$ & $6,926,667$ \\
$45-49$ & $7,619,167$ \\
$50-54$ & $8,311,833$ \\
$55-59$ & $9,004,500$ \\
$60-64$ & $9,904,833$ \\
$65-69$ & $10,805,333$ \\
\hline
\end{tabular}

Table 2 Valuation comparison of the models

\begin{tabular}{|c|c|c|c|c|c|c|}
\hline & $\begin{array}{c}\text { Investment } \\
\text { (million IDR) }\end{array}$ & $\begin{array}{c}\text { NCF } \\
\text { (million IDR) }\end{array}$ & $\begin{array}{c}\text { NPV } \\
\text { (million IDR) }\end{array}$ & $\begin{array}{l}\text { IRR } \\
(\%)\end{array}$ & $\mathrm{P} / \mathrm{I}$ & $\begin{array}{r}\text { PBP } \\
\text { (years) }\end{array}$ \\
\hline Model 1 & 610.91 & 170.66 & $(75.95)$ & 6.83 & 0.28 & 5.92 \\
\hline Model 2 & 879.60 & $2,020.96$ & 407.74 & 21.38 & 2.30 & 10.03 \\
\hline Model 3 & 961.33 & $322,330.28$ & $20,741.98$ & 34.47 & 335.29 & 16.00 \\
\hline Model 4 & $2,019.13$ & $364,458.81$ & $26,625.94$ & 35.85 & 180.50 & 16.09 \\
\hline
\end{tabular}

Table 3 The CPI, AEV, and BCR methods

\begin{tabular}{|c|c|c|c|c|c|c|c|c|c|c|}
\hline & \multicolumn{6}{|c|}{ Transformed Matrix } & \multirow{2}{*}{$\begin{array}{c}\text { Alternate } \\
\text { Value }\end{array}$} & \multirow{2}{*}{ Rank } & \multirow{2}{*}{$\begin{array}{c}\text { AEV } \\
\text { (million IDR) }\end{array}$} & \multirow{2}{*}{$\mathrm{BCR}$} \\
\hline & Investment & $\mathrm{NCF}$ & NPV & IRR & $\mathrm{P} / \mathrm{I}$ & PBP & & & & \\
\hline Model 1 & 100 & 100 & 100 & 100 & 100 & 100 & 100 & 4 & $(15.29)$ & 0.88 \\
\hline Model 2 & 69 & 1,184 & 268 & 313 & 821 & 59 & 532 & 3 & 58.47 & 1.39 \\
\hline Model 3 & 64 & 188,873 & 13,655 & 505 & 119,746 & 37 & 63,907 & 1 & $2,627.01$ & 16.14 \\
\hline Model 4 & 30 & 213,558 & 17,529 & 525 & 64,464 & 37 & 58,372 & 2 & $3,372.22$ & 19.94 \\
\hline Weight & 0.05 & 0.20 & 0.15 & 0.25 & 0.20 & 0.15 & & & & \\
\hline
\end{tabular}

IDR364,458.81 million, an NPV of IDR26,625.94 million, and an IRR of $35.85 \%$ at the expense of highest total investment (i.e. IDR2,019.13 million) and longest payback period (i.e. 16.09 years). To overcome a long period of $P B P$, Sugiharto (2013) proposed a financing strategy in which three stages were proposed. The first stage being developed by initiator would result in a long period of payback unless the second stage was introduced. The second stage being proposed was private placement so that the initiator would recover its investment with profit in year four. Further, stage three being proposed by Sugiharto (2013) at year 6 was public offering so that the private placement party will recover its investment and profit in two years time. As a public company, shareholders are able to trade their shares at any time independence to harvesting time (Sugiharto 2013).

The output of the valuation in Table 2 was analysed further by using CPI, AEV, and BCR methods (Table 3 ). This table indicates that Model 3 is the most preferred alternative 
with an alternate value of 63,907 being followed by Model 4 with an alternate value of 58,372; whereas Model 1 and Model 2 that represent early harvesting schedules earn the lowest preferred rank with alternate values of 100 and 532, respectively.

In terms of AEV, Model 4 gave the best outcome at a value of IDR3,372.22 million being followed with Model 3 at a value of IDR2,627.01 million. The AEV of Model 1 was a lost at a value of IDR15.29 million, whereas the AEV of Model 2 was IDR58.47 million. The AEV results were consistent with the BCR results in which Model 4 is the best with a BCR of 19.94 being followed with Model 3 with a $B C R$ of 16.14. Model 3 yield a BCR of 1.39 whereas Model 1 yield a BCR of 0.88 respectively. Again, the BCR of 0.88 in Model 1 indicates that the benefit of the model is less than the costs being spent.

\section{Conclusion}

It is concluded that despite the fastest payback period and lowest investment, Model 1 yields a negative NPV, negative $\mathrm{AEV}$, and a benefit that less than the costs. This is supported with the lowest preferred rank of the CPI analysis. Model 3 and Model 4 that represent longer harvesting schedules yield better outcomes. In term of financing strategy, the long payback period due to longer harvesting schedules could be overcome by private placement and public offering. The preference on Model 3 and Model 4 is depend on the individual investor's criteria. For investors that more concern on less total investment and highest profit on investment, Model 3 is the best choice; however, for investors that more concern on net cash flow, net present value, and internal rate of return, Model 4 gives the best outcome. In general, AEV, $\mathrm{BCR}$, and CPI are consistent to support the other common valuation criteria. Therefore, investors should carefully evaluate any investment opportunity being offered by private enterprises by applying other supporting methods as well as applying proper financing strategy to ensure the best outcome of the investment.

\section{References}

Abi-Ghanem R et al. 2009. Extension education for dryland cropping systems in Iraq. Journal of Natural Resources and Life Sciences Education 38:133-139.

Acosta-Martínez V et al. 2011. Dryland cropping systems influence the microbial biomass and enzyme activities in a semiarid sandy soil. Biology and Fertility Soils 47:655-667. http://dx.doi.org/10.1007/s00374-0110565-1.

Amacher GS, Koskela E, Ollikainen M. 2009. Deforestation and land use under insecure property rights. Environment and Development Economics 14(3):281-303. http://dx.doi.org/10.1017/S1355770X0800483X.

Bailey JD, Harjanto NA. 2005. Teak (Tectona grandis L.f) tree growth, stem quality and health in coppiced plantations in Java, Indonesia. New Forests 30:55-65.
[BAPPEDA DIY] Badan Perencana Pembangunan Daerah Provinsi Yogyakarta. 2012. Analisis Produk Domestik Regional Bruto Provinsi Daerah Istimewa Yogyakarta 2007-2011.

Benhin JKA. 2006. Agriculture and deforestation in the tropics: A critical theoretical and empirical review. Ambio 35(1):9-16. http://dx.doi.org/10.1579/00447447-35.1.9.

[BPS] Badan Pusat Statistik Republik Indonesia. 2010. Perkembangan Beberapa Indikator Utama SosioEkonomi Indonesia. Katalog BPS:3101015.

Carberry PS, Bruce SE, Walcott JJ, Keating BA. 2011. Innovation and productivity in dryland agriculture: a return-risk analysis for Australia. The Journal of Agricultural Science 149:77-89. http://dx.doi.org/10. 1017/S0021859610000973.

Djagbletey GD, Adu-Bredu S. 2007. Adoption of agroforestry by small scale teak farmers in Ghana-The case of Nkoranza District. Ghana Journal of Forestry 20\&21:1-13.

Fuglie KO. 2010. Sources of growth in Indonesian agriculture. Journal of Prod Anal. 33:225-240. http://dx.doi.org/10.1007/s11123-009-0150-x.

Gittinger JP. 1982. Economic Analysis of Agricultural Projects. Baltimore-Maryland: The John Hopkins University Press.

Godsey LD. 2008. Economic Budgeting for Agroforestry Practices. USA: University of Missouri Center for Agroforestry.

Hallett JT, Díaz-Calvo J, Villa-Castillo J, Wagner MR. 2011. Teak plantations: economic bonanza or environmental disaster? Journal of Forestry 109(5):288-292.

JAR. 2012. Planting God's Way: Fast Growing-Price Growing. PT. Jaty Arthamas Rizky.

Kademani SBK. 2011. Resource use efficiency of dryland ragi cultivators in DPAP-watershed and non-watershed areas: A composite analysis. The IUP Journal of Agricultural Financials 8(1):18-27.

Kangalawe RYM, Lyimo JG. 2010. Population dynamics, rural livelihoods and environmental degradation: some experiences from Tanzania. Environment, Development and Sustainability 12:985-997. http://dx.doi.org/10. 1007/s10668-010-9235-y

Kay RD, Edwards WM, Duffy PA. 2012. Farm Management. New York: McGraw-Hill.

Lalramnghunaglova JH, Jha LK. 1996. Prominent agroforestry systems and important multi-purpose trees in 
farming system of Mizoram. Special issue: agro-forestry. Indian Forester 7:604-609.

Marimin, Maghfiroh N. 2010. Aplikasi Teknik Pengambilan Keputusan dalam Manajemen Retail Pasok. Bogor: PT Penerbit IPB Press.

Ministry of Finance Republic of Indonesia. 2012. Hasil Lelang Surat Utang Negara SPN12131204 pada hari Senin, tanggal 3 Desember 2012, Nomor: 183/HMS/2012. Jakarta: Kementerian Keuangan Republik Indonesia Biro Komunikasi dan Layanan Informasi.

Pérez D. 2008. Growth and volume equation developed from stem analysis for Tectona grandis. Journal of Tropical Forest Science 20(1):66-75.

Perhutani. 2011. Harga Jual Dasar (HJD) Tahun 2012. Keputusan Direksi Perum Perhutani Nomor: 1148/Kpts/Dir/2011, 30 Desember 2011. Perum Perhutani Unit II Jawa Timur Biro Pemasaran dan Trading.

Pramono AA et al. 2010. Pengelolaan Hutan Jati Rakyat: Panduan Lapangan untuk Petani. Bogor: Center for International Forestry Research.

Quaye AK, Hall CAS, Luzadis VA. 2010. Agricultural land use efficiency and food crop production in Ghana. Environment, Development and Sustainability. 12:967-983. http://dx.doi.org/10.1007/s10668-0109234-z.

Rabia KA, Solowey E, Leu S. 2008. Environmental and financial potential of Bedouin dryland agriculture. A case study in the Northern Negev, Israel. Journal of Management of Environmental Quality 19(3):353-366.

RECOFTC. 2010. The Role of Social Forestry in Climate Change Mitigation and Adaption in the ASEAN Region. RECOFTC-The Center for People and Forests, Thailand;
ASEAN Social Forestry Network Secretariat, Indonesia; Swiss Agency for Development and Cooperation (SDC), Switzerland.

Reuters. 2013. http://www.reuters.com/finance/stocks/ overview?symbol=. [15 February 2013].

Ryan J, El-Mourid M, Shroyer JP, Gharous ME. 2007. The dryland agriculture applied research project in Morocco: A perspective 12 years after completion. Journal of Natural Resources and Life Sciences Education 36:120-128.

Salvatore D. 2008. Managerial Financials: Principles and Worldwide Applications. Sixth Edition. Oxford: Oxford University Press.

Soeroso H, Poedjowadi D. 2009. Ekonomi Kerakyatan dalam Praktek: Usahatani Jati Unggul Pola Bagi Hasil 5 Tahun Panen. Unit Usaha Bagi Hasil Koperasi Perumahan Wanabakti Nusantara (UBH-KPWN).

Soeleman S, Gumbira-Sa'id E, Daryanto HKS, Suroso AI. 2013. Small-scale community-based dryland agroforestry in Yogyakarta, Indonesia. Social Science Letters 3(1):20-29.

Sugiharto. 2013. Business development model of integrated agribusiness in dryland areas of Yogyakarta [dissertation]. Bogor: Bogor Agricultural University.

Washington-Allen RA, West NE, Ramsey RD, Phillips DH, Shugart HH. 2010. Retrospective assessment of dryland soil stability in relation to grazing and climate change. Environmental Monitoring and Assessment 160(1-4):101-121. http://dx.doi.org/10.1007/s10661008-0661-3

Young $\mathrm{G}$ et al. 2010. Vulnerability and adaptation in a dryland community of the Elqui Valley, Chile. Climatic Change. 98:245-276. http://dx.doi.org/10.1007/s10584009-9665-4. 